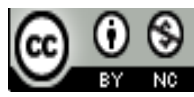

Jurnal Ilmu Pendidikan Fisika is licensed under

A Creative Commons Attribution-Non Commercial 4.0 International License.

\title{
Penggunaan Model Problem Based Learning Berbantuan Media KIT EKSPERIMEN INKUIRI TERHADAP PENINGKATAN PENGUASAAN KonSEP SiSWA KelaS XI SMK PADA MATERI FLUIDA STATIS
}

\author{
Sudirman ${ }^{1)}$, Johar Maknun ${ }^{2)}$, Lilik Hasanah ${ }^{3)}$ \\ 1) Universitas Nahdlatul Ulama Kalimantan Barat, Pontianak, Indonesia \\ E-mail: sudirmanismail365@unukalbar.ac.id \\ 2) Universitas Pendidikan Indonesia, Bandung, Indonesia \\ E-mail:joharmaknun@upi.edu \\ 2) Universitas Pendidikan Indonesia, Bandung, Indonesia \\ E-mail:lilikhasanah@upi.edu
}

\begin{abstract}
Abstrak. Tujuan penelitia ini adalah untuk memperoleh gambaran penggunaan model probelem based learning untuk meningkatkan peguasaan konsep siswa SMK kelas XI pada materi fluida statis serta untuk memperoleh gambaran tanggapan siswa terhadap model problem based learning. Metode penelitian yang digunakan adalah eksperimen semu dengan desain "pretest-posttest control group design" yang dilaksanakan di kelas XI pada salah satu SMK di kabupaten Sambas untuk tahun pelajaran 2011/2012. Pengumpulan data dilakukan dengan menggunakan tes awal dan tes akhir untuk pengguasaan konsep siswa serta angket untuk mengetahui tanggapan siswa terhadap model problem based learning. Berdasarkan hasil analisis data diperoleh rata-rata N-gain penguasaan konsep siswa 0,33 untuk kelas eksperimen dan 0,206 untuk kelas kontrol. Hasil uji hipotesis menggunakan uji t dua sampel independen dengan SPSS 16 menunjukkan bahwa peningkatan penguasaan konsep siswa yang mengikuti pembelajaran dengan model problem based learning berbantuan media eksperimen inkuiri lebih tinggi dibandingkan siswa yang mengikuti pembelajaran dengan problem based learning dengan metode praktikum bebas. Disimpulkan bahwa pembelajaran dengan pendekatan problem based learning dengan eksperimen inkuiri secara signifikan dapat lebih meningkatkan penguasaan konsep dan siswa dibandingkan dengan pembelajaran problem based learning dengan praktikum bebas.
\end{abstract}

Kata Kunci: Model problem based learning; praktikum inkuiri; penguasaan konsep; fluida statis

\section{PENDAhUluan}

Kurikulum SMK terdiri atas berbagai kelompok mata pelajaran salah satunya adalah kelompok Ilmu Pengetahuan Alam (IPA). Salah satu komponen mata pelajaran IPA di dalam struktur kurikulum SMK yaitu Fisika. Fisika sebagai salah satu cabang IPA yang pada dasarnya bertujuan untuk mempelajari dan menganalisis pemahaman kuantitatif gejala atau proses alam dan sifat zat serta penerapannya. Selain itu Haratua, Stepanus, Hairida [6] mengatakan bahwa dalam pelajaran fisika selain selain mempelajari peristiwa atau fenomena alam juga dapat berperan untuk melatih siswa berpikir secara kritis.

Selain berpikir kritis siswa juga di tuntut untuk menguasai konsep-konsep yang ada dalam Fisika [10]. Rosser [5] mengatakan bahwa konsep merupakan suatu abstraksi yang mewakili satu kelas objek-objek, kejadian-kejadian, kegiatan- kegiatan, atau hubungan-hubungan, yang mempunyai atributatribut yang sama. Karena itu merujuk pada pernyataan tersebut dan tidak ada dua orang yang memiliki pengalaman yang persis sama, maka konsep-konsep yang dibentuk orang mungkin berbeda pula. Untuk memecahkan masalah, seorang siswa harus mengetahui aturan-aturan yang relevan, dan aturan-aturan ini didasarkan pada konsep-konsep yang diperolehnya [9].

Untuk memahami konsep-konsep abstrak dalam fisika secara umum dibutuhkan kemampuan penalaran yang tinggi. Proses pembelajaran fisika tidak mengutamakan banyaknya pengetahuan yang dapat diperoleh, tetapi lebih kepada pengembangan kemampuan dan keterampilan siswa untuk dapat belajar lebih lanjut. Apabila hal ini diterapkan dalam materi fluida statis, maka bentuk pembelajaran fluida statis sebaiknya dapat mengembangkan kemampuan-kemampuan dasar siswa. 


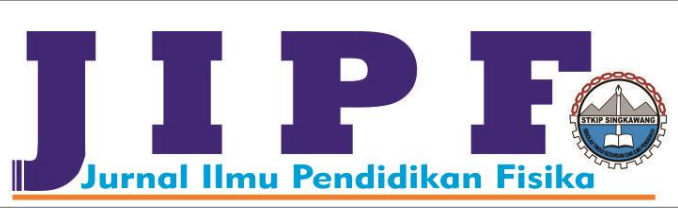

Salah satu masalah pokok dalam pembelajaran adalah masih rendahnya daya serap peserta didik [8]. Penyataan ini sesuai dengan hasil wawancara peneliti dengan guru fisika pada salah satu SMK di Kabupaten Sambas untuk mata kuliah studi kasus, guru mengatakan bahwa siswa SMK N 1 Paloh mengalamai kesulitan dalam memahami konsep fisika, dan bahkan siswa lebih cepat lupa dengan materi fisika yang telah diajarkan. Selain itu, di sekolah SMK N 1 Paloh Kabupaten Sambas Kalimantan Barat siswa juga tidak pernah melakukan atau melaksanakan praktikum fisika karena sekolah ini sekolah baru sehingga alat-alat laboratorium fisika belum ada. Selain itu KKM yang harus dicapai pada materi fisika adalah 70 namun rata-rata siswa belum mencapai KKM yang telah di tetapkan oleh sekolah.

Oleh karena itu dalam penelitian yang direncanakan penulis akan mamanfaatkan sebuah media pembelajaran berupa set eksperimen fluida statis dengan menggunakan model pembelajaran problem based learning. Set eksperimen ini dapat digunakan untuk melakukan percobaan pada materi fluida statis, set eksperimen ini dibuat dari material lokal dan bahan sisa industri yang manfaatnya membantu guru mengatasi masalah kekurangan set eksperimen fisika di sekolah. Dengan demikian pelaksanaan praktikum di sekolah dapat terlaksanakan dengan baik. Selain itu guru lebih inovatif dan dapat merancang sendiri eksperimen yang di inginkan. Penggunaan set eksperimen sebagai media pembelajaran pada tahap orientasi pembelajaran akan sangat membantu keefektifan proses pembelajaran dan penyampaian pesan dan isi pembelajaran pada saat itu.

Menurut Dutch [2] problem based learning merupakan metode instruksional yang menantang siswa agar "belajar untuk belajar" bekerja sama dalam kelompok untuk mencari solusi bagi masalah yang nyata. Masalah ini digunakan untuk mengaitkan rasa keingintahuan serta kemampuan analisis siswa dan inisiatif atas materi pelajaran. Problem based learning mempersiapkan siswa untuk berpikir kritis, berfikir analitis, dan untuk mencari serta menggunakan sumber belajar yang sesuai. Pernyataan tersebut ditunjang oleh pendapat Smit [2] yang mengemukakan manfaat dari problem based learning adalah dapat meningkatkan kecakapan pemecahan masalah, lebih mudah mengingat, meningkatkan pemahaman, meningkatkan pengetahuan yang relevan dengan dunia praktik, mendorong mereka penuh pemikiran, membangun kemampuan kepemimpinan, kerja sama, kecakapan belajar dan memotivasi pembelajar.

Materi fluida statis merupakan materi pelajaran fisika yang selalu muncul pada soal Ujian Nasional (UN). Materi fluida statis dipandang perlu mendapat perhatian untuk dilakukan penelitian. Berdasarkan masalah di atas peneliti tertarik untuk meneliti dengan judul: Penggunaan Model Problem Based Learning Terhadap Peningkatan Penguasaan Konsep Siswa Kelas XI SMK Pada Materi Fluida Statis dengan rumusan masalah sebagai berikut: "Apakah penggunaan model problem based learning dapat meningkatkan penguasaan konsep siswa kelas XI SMK pada materi fluida statis?"

\section{MetodE}

Desain yang digunakan dalam penelitian ini adalah kuasi eksperimen "pretest-posttest control group designe" [1] yang penentunya dilakukan secara acak kelas.

Dalam penelitian ini memiliki 3 tahapan yang dilaksanakan dalam penelitian, yaitu:

1) Tahap perencanaan, dimana dalam tahapan ini peneliti melakukan studi pendahuluan berupa menganalisis kurikulum dan studi pendahuluan kesekolah, merumuskan masalah, studi literatur, merumuskan perangkat pembelajaran dan instrument penelitian, menguji validitas isntrumen dan perangkat pembelajaran, melakukan revisi instrument dan perangkat pembelajaran, dan menguji coba perangkat pembelajaran

2) Tahap pelaksanaan, dimana dalam tahapan ini peneliti memberikan pretest, memberikan perlakuan untuk kelas eksperimen dan kelas kontrol, melakukan observasi kegiatan belajar mengajar, dan memberikan Posttest.

3) Tahapan akhir; dimana dalam tahapan ini peneliti mengolah data hasil penelitian (dengan menghitung nilai $\mathrm{N}$-gain, dan menguji hipotesis) pertama melakukan uji normalias menggunakan one-sample Kolmogorovsumirnov test; kedua, melakukan uji homogenitas menggunakan levene's test; ketiga, pengujian hipotesis menggunakan uji T-test (independent samples test). dan menarik kesimpulan.

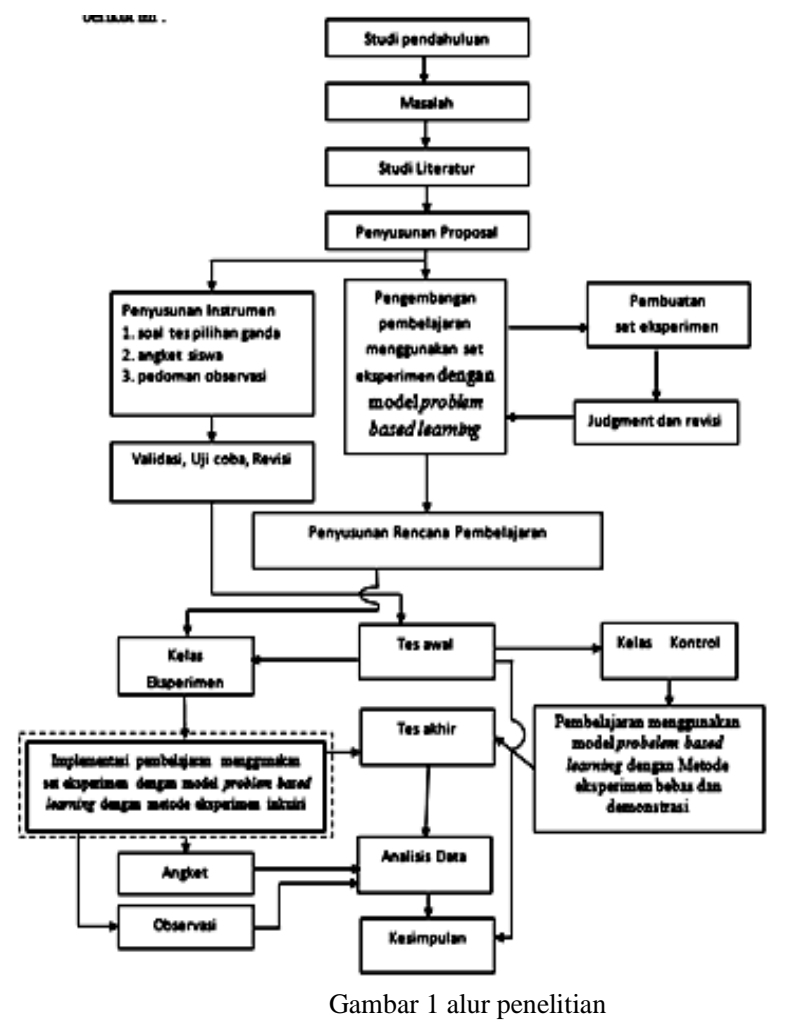

\section{HASIL DAN PEMBAHASAN}

Peningkatan penguasaan konsep siswa dapat diperoleh dari data hasil posttest dikurangi pretest (gain) yang kemudian diperoleh gain yang dinormalisasi ( $\mathrm{N}$-gain) pada kelompok 


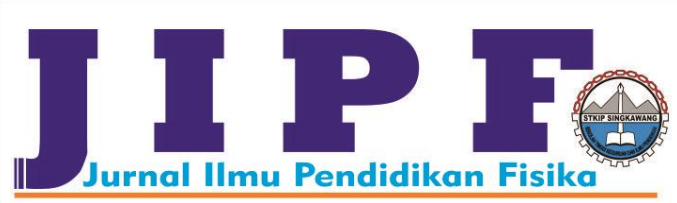

eksperimen dan kontrol. Grafik skor pretest, posttest dan gain kelas eksperimen dan kelas kontrol disajikan secara lengkap pada Gambar 2.

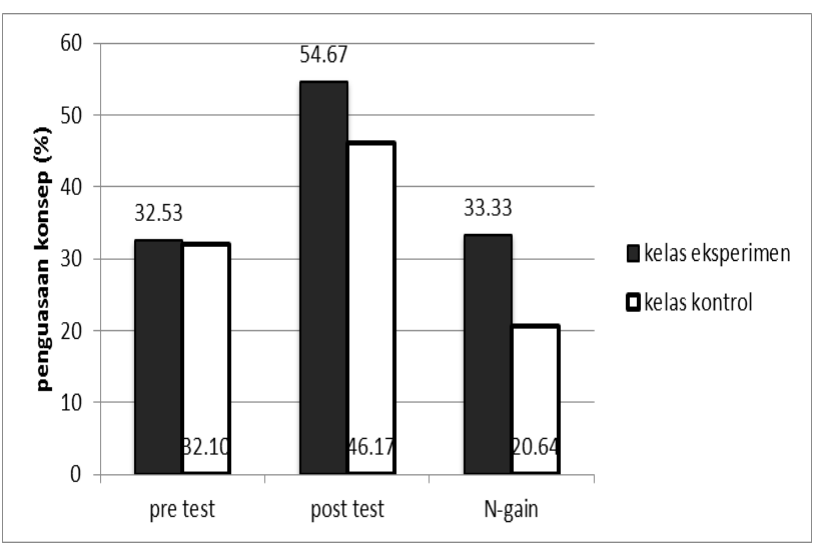

Gambar 2 Skor Pretest, postest dan gain kelas eksperimen dan kelas kontrol

Berdasarkan Gambar 2 , d1ketanu1 persentase skor rata-rata pretest kelas eksperimen sebesar 32,53\%, sedangkan skor rata-rata kelas kontrol sebesar 32,10\%. Artinya penguasaan konsep yang dimiliki siswa kelas eskperimen dan kelas kontrol sebelum perlakuan tidak memiliki perbedaan yang signifikan. Skor rata-rata posttest kelas esperimen diperoleh sebesar 54,67 \%, sedangkan skor rata-rata posttest kelas kontrol sebesar 46,17\%.

Untuk mengetahui pada indikator penguasaan konsep yang mana mengalami peningkatan dapat dilihat dengan cara melihat peningkatan skor pretest, skor postest dan gain tiap indikator penguasaan konsep. Penguasaan konnsep dari tiap indikator penguasaan konsep selengkapnya disajikan pada Gambar 3.

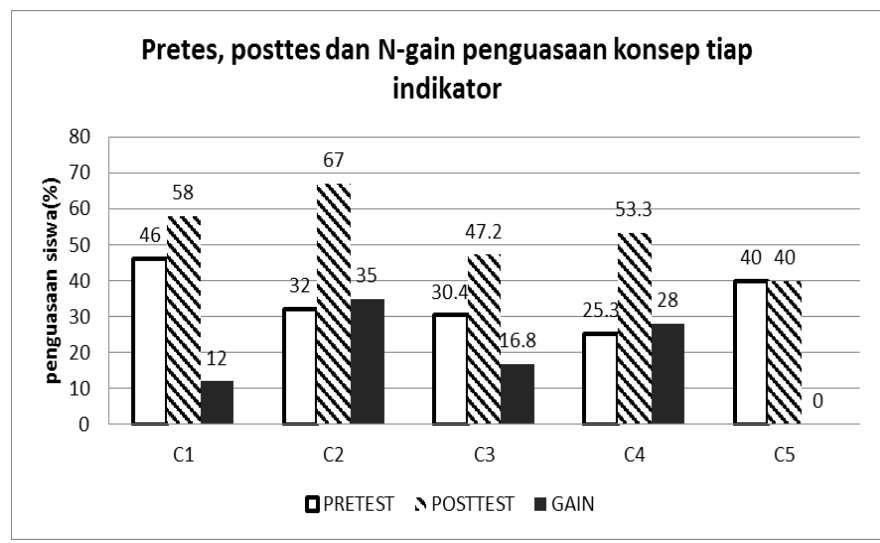

Gambar 3. Diagram pretest, posttest dan N-gain penguasaan konsep tiap indikator

Berdasarkan Gambar 3 terlihat diagram pretst, posttest dan $\mathrm{N}$-gain untuk tiap indikator penguasaan konsep. Besarnya peningkatan indikator penguasaan konsep ada pada indikator C2 (memahami) dengan besar pretest 32\%, posttest $67 \%$ dan nilai N-gainnya sebesar $35 \%$. Sedangkan peningkatan indikator pengusaan konsep terkecil adalah terletak pada C5 (mengevaluasi) dimana besar pretest sebesar $40 \%$, posttest sebesar 40\% dan nilai $\mathrm{N}$-gainnya sebesar 0\% (tidak terdapat peningkatan).

Berdasarkan skor dan hasil analisis data pretest, posttest dan $\mathrm{N}$-gain terhadap kemampuan penguasaan konsep, siswa yang mendapatkan pembelajaran berbasis masalah menunjukkan bahwa secara keseluruhan kemampuan penguasaan konsep siswa kelas eksperimen lebih baik dibandingkan siswa kelas kontrol. Hal ini ditunjukkan dengan adanya perbedaan perolehan nilai gain yang dinormalisasi dari kedua kelas yang dapat dilihat pada tabel 1 dimana peningkatan yang dialami oleh kelas eksperimen sebesar $33,33 \%$ sedangkan peningkatan yang dialami oleh kelas kontrol sebesar 20,46\%. Tingginya perolehan skor gain kelas eksperimen disebabkan karena dalam pembelajaran berbasis masalah memberi peluang bagi siswa untuk lebih leluasa dalam belajar secara mandiri, saling bertukar pikiran dengan sesamanya, dan saling membantu dalam menyelesaikan setiap tugas yang diberikan oleh guru. Hal tersebut sejalan dengan pandangan yang dikemukakan oleh Bruner [8] menyatakan bahwa berusaha sendiri untuk mencari pemecahan masalah serta pengetahuan yang menyertainya menghasilkan pengetahuan yang benar-benar bermakna. Karena dengan berusaha untuk mencari pemecahan masalah secara mandiri akan memberikan suatu pengalaman konkret, dengan pengalaman tersebut dapat digunakan pula memecahkan masalah-masalah serupa, karena pengalaman itu memberikan makna tersendiri bagi peserta didik. Arends [3] juga mengatakan PBL memiliki akar intelektual yang sama dengan inquiry teaching dan cooperative learning. Esensi dari PBL berupa menyuguhkan berbagai situasi bermasalah yang autentik dan bermakna kepada siswa yang dapat berfungsi sebagai batu loncatan untuk investigasi dan loncatan. Sehingga pada fase penyelidikan dalam pembelajaran siswa akan didorong untuk mengajukan pertanyaan dan berupaya untuk mendapatkan informasi sendiri. guru hanya menyediakan bantuan, namun seharusnya siswa berusaha secara mandiri atau bersama teman-temannya [7].

Setelah dilakukan pembelajaran pada kedua kelompok dengan metode yang berbeda, selanjutnya diberikan postest untuk mengetahui kemampuan siswa dalam menyelesaikan soal. Kemudian dilakukan analisis terhadap data data gain yang dinormalisasi kedua kelas. Dari hasil analisis tersebut, ternyata kedua kelas mengalami peningkatan kemampuan dalam menyelesaikan soal, terutama pada penguasaan konsep. Peningkatan yang terjadi pada kelas eksperimen lebih tinggi ( $\mathrm{N}$-gain 0,33) daripada kelas control $(\mathrm{N}$-gain 0,20). Hal tersebut sejalan dengan pandangan yang dikemukakan Arends [3] bahwa belajar berbasis masalah adalah salah satu pendekatan pembelajaran yang bertujuan untuk mengembangkan pengetahuan-pengetahuan dasar, keterampilan-keterampilan berpikir tingkat tinggi.

Hasil perhitungan dengan menggunakan SPSS 16 diperoleh signifikansi pada kelas eksperimen sebesar 0,304. Signifikan $0,304>0,05$ artinya data gain kelas eksperimen terdistribusi normal. sedangkan signifikansi kelas kontrol di peroleh sebesar 0,257. Dan hasil perhitungan homogenitas menggunakan SPSS 16 diperoleh signifikansi sebesar 0,508> 
0,05 artinya data pretest kelas eksperimen dan kelas kontrol adalah homogen.

Hasil pengujian hipotesis penguasaan konsep menunjukkan taraf signifikansi untuk pretest sebesar 0,855. Karena signifikansi >0,05, maka dapat dikatakan bahwa tidak terdapat perbedaan yang signifikan penguasaan fluida statis antara siswa kelas eksperimen dan kelas kontrol sebelum penerapan model pembelajaran. Hal ini berarti bahwa kelas eksperimen yang menggunakan model problem based learning dengan berbantuan media kit eksperimen inkuiri dapat meningkatkan hasil belajar siswa secara signifikan dibandingkan dengan pembelajaran menggunakan model problem based learning dengan praktikum bebas. Peningkatan penguasaan konsep dengan model problem based learning dengan praktikum inkuiri karena model pembelajaran yang digunakan dapat menumbuhkan keinginan siswa untuk mempelajari materi fluida statis.

\section{KESIMPULAN}

Berdasarkan data dan analisis hasil penelitian yang telah dilakukan tentang pembelajaran menggunakan pendekatan problem solving dengan strategi SSCS untuk meningkatkan hasil belajar siswa aspek kognitif dapat disimpulkan bahwa:

1. Model Problem Based Learning dapat lebih meningkatkan penguasaan konsep siswa dibanding dengan pembelajaran yang dilaksanakan pada kelas kontrol.

2. Tanggapan siswa setelah belajar menggunakan model problem based learning pada konsep fluida statis memberikan respon positif, siswa merasakan bahwa materi ini sangat bermanfaat dalam kehidupan sehari-hari karena fluida statis dapat ditemukan secara langsung.
Jurnal Ilmu Pendidikan Fisika

Volume 2 Number 2 month September 2017. Page 38-41 p-ISSN: 2477-5959 e-ISSN: 2477-8451

\section{UCAPAN TERIMAKASIH}

Kami ingin mengucapkan terima kasih kepada Causal Productions atas izin untuk menggunakan dan merevisi template yang disediakan oleh Causal Productions. Versi asli dari template ini diberikan oleh Causal Productions (www.causalproductions.com).

\section{DAFTAR PUSTAKA}

[1] Fraenkell, J.R. and Wallen, N. (1993). How to design and evaluate research in education, N.Y: Mc. Graw Hill.Amir. (2010).

[2] Inovasi Pendidikan Melalui Problem Based Learning Bagaimana Pendidik Memberdayakan Pemelajar Di Era Pengetahuan. Jakarta: Kencana.

[3] Arends. (2008). Learning To Teach belajar untuk mengajar (seventh ed). Yogyakarta: Pustaka Pelajar

[4] Arsyad. (2007), Media Pembelajaran, Jakarta: Raja grafindo persada

[5] Dahar, R.W. (1996), Teori-teori belaja, Jakarta: Erlangga

[6] Haratua, Stepanus, Hairida. (2002), Penerapan Model Belajar Generatif Dalam Pembelajaran Fisika di SMU, Pontianak: FKIP UNTAN.

[7] M. Nur. (2011). Model Pembelajaran Berdasarkan Masalah jilid 2, Surabaya: Universitas Negeri Surabaya

[8] Trianto. (2007). Model-model Pembelajaran Inovatif Berorientasi Konsrtruktivistik, Jakarta: Prestasi Pustaka

[9] Rosdianto, H., Murdani, E., dan Hendra. 2017. The Implementation of POE (Predict Observe Explain) Model to Improve Student's Concept Understanding on Newton's Law. Jurnal Pendidikan Fisika Unimed, 6(1): 55-57.

[10] Rosdianto, H. 2017. Pengaruh Model Generative Learning Terhadap Hasil Belajar Ranah Kognitif Siswa Pada Materi Hukum Newton. Jurnal Pendidikan Fisika dan Keilmuan (JPFK), 3(2): 66-69. 